\title{
The Interplay of Stakeholder Theory and Blind Spot Theory in Rural Tourism Development
}

\begin{abstract}
By Per Åke Nilsson ${ }^{*} \&$ Jessica Aquino ${ }^{ \pm}$
This paper explores the emergence of Stakeholder Theory and Blind Spot Theory over time from two distinct points of views in rural tourism development. After World War II, community development in most rural European areas have been challenged by negative demographic situations caused by centripetal economic development. In order to stabilize vital economic development, new or well-established initiatives have adopted different rural tourism development projects. Most of these projects include local stakeholders from both the private and public sectors. Using a longitudinal multiple case study analysis combined with a comparative method, this study reveals two points of views (stakeholder theory and blind spot theory). Three cases have been chosen in sparsely populated areas in Mid Sweden. This longitudinal study describes outcomes, measured by an estimation of their degree of development success or failures regarding their demographic situation over a span of thirty years. Implications are discussed concerning the rural tourism development process with recommendations of a best practice approach.
\end{abstract}

Keywords: community development, rural tourism, stakeholder theory, blind spot theory, Nordic periphery

\section{Introduction}

The backdrop for this research is the ongoing depopulation of peripheral Nordic regions. After World War II, community development in most rural European areas have been challenged by negative demographic situations caused by centripetal forces moving economic development towards the center (or bigger cities). Strengthening of centripetal forces can lead to economic conflicts and political problems (Bondarenko et al. 2017). The larger market of bigger cities would be able to attract additional economic activity to the center while the periphery would lose business (Dluhosch 2000). In order to stabilize vital economic development in the rural countryside, our cases describe how communities have had to adopt different rural tourism development projects.

An industrial development boom occurred during the 1950s in most of the European industrial regions as a result of the reconstruction after World War II (Apostle and Barret 1992, Hall and Gieben 1992). In Scandinavia, this was done by a rationalization of small agricultural entities, often by relinquishing them, materialized by moving people from the north to the south. This resulted in substantial drainage of people in active ages in these areas (Adey 2010, Nilsson

\footnotetext{
*Affiliated Faculty, Department of Rural Tourism, Hólar University, Iceland \& The European Tourism Research Institute (ETOUR), Mid Sweden University, Sweden.

${ }^{ \pm}$Assistant Professor, Department of Rural Tourism, Hólar University, Iceland.
} 
2013). During the 1970s, this development was counteracted in both political and economic manifestations by domestic public opinions (Gustafsson 1991) and by international researchers (Armstrong and Taylor 1993). In the 1980s a so-called "green" movement occurred where a large amount of mostly young people moved to rural areas in the north (Getz and Nilsson 2004, Dahlström et al. 2006). However, this counteraction of development did not stop the on-going brain drain from the countryside (Aarsæther and Bærenholdt 2001, Granquist et al. 2019).

Our longitudinal case study analysis of three Swedish periphery municipalities that tried to roll back their negative development and find a new future reveals the emergence and interplay of two distinct theories (stakeholder theory and blind spot theory) in rural tourism community development projects. Most of these projects include local stakeholders from both the private and public sectors. This paper aims to see how these two theories unintentionally can match or disturb each other by coping with the challenges small rural villages face in sparsely populated regions threatened by total extinction. The main research question for our multiple case study was, "What are the outcomes or interactions of two distinct points of views (stakeholder theory and blind spot theory) in community development or revitalization projects of three Swedish periphery municipalities?" Implications are discussed concerning rural tourism development process with recommendations of a best practice approach.

\section{Literature Review}

\section{Rural Tourism Development in the Nordic Periphery}

Living in small rural areas often has associated stigma linked to perceptions of poverty or lack of education and cultural un-refinement. For example, as discussed by Salvatore et al. (2018, p. 42) that “... the meaning of the term 'periphery' itself has carried social, political and economic implications, often becoming a synonym for marginalization..." Many rural peripheral areas are at an economic disadvantage because of centripetal forces both from economic development and migration towards the center (Nilsson 2013). Because of their remoteness, rural areas are often excluded from development policies which are written in cities or the capital area. Adequate infrastructure, such as education, health care, recreation (Jana and Marián 2012) and technological infrastructure (Salvatore et al. 2018) is also often lacking causing a negative decline in population. Rural areas are more vulnerable to out migration as young individuals and families move to larger cities for work or for education.

Rural tourism has been seen as a way of cultural transformation of the rural peripheries moving it from a place of abandonment to a place of quality (Salvatore et al. 2018) while tourism has been used for regional development and helping rural farming families maintain their way of life (Aquino and Burns 2021). Furthermore, tourism employment in peripheral areas has been found to be a pull factor of skilled workers creating a more dynamic and vibrant community (Thulemark et al. 2014). The benefits of 'in-movers' (a person who has moved to 
the area for the first time) and back-movers (a person who has left the area and then moved back) (Nilsson et al. 2011) is that they counteract the negative effect of the decline of human capital from a persistent outmigration of young people. Although not always a success story, tourism is seen as a way of overcoming obstacles to regional development by capitalizing on their remoteness and the idea of wilderness (Brouder 2013), sense of place (Aquino and Kloes 2020), and cultural heritage experience (Salvatore et al. 2018). However, tourism alone cannot be the sole driving force for regional development, rather it should be part of a larger plan that helps to strengthen community assets.

\section{Theories}

\section{Stakeholder Theory}

Stakeholders as a concept is defined as a pressure group within a community or a destination, who can affect or is affected by the achievement of the organization's objectives (Freeman et al. 2010). Such alliances can be loose arrangements or separate organizations, that form prerequisites for a successful development processes (Terpstra and Simonin 1993, Jamal and Getz 1994, Cancino 2014). The local political system often acts as a convenor, or organizer, with inherent interests in the continuous development of the destination (Baldacchino and Milne 2000, Martin 2001, Timur and Getz 2002, Freeman 2010). These stakeholders can also convey interdependency between actors (preferably all) in order to gain collective benefits for the whole destination. This is especially relevant for small family businesses (Ankre and Nilsson 2016, Richardson 2015).

Stakeholder theory can also contribute to a change of identity of a destination by developing new attributes with collective and regional identity (Backman 2015). Bauman (2017) complicates the theory by stating that every development is an eternal repetition of previous conditions, but with different winners and losers; and without Hegel's presumption that the development advances from good to better. For example, Brooks (2020, p. 5) describes a Hegelian-inspired interpretation of stakeholders as "not merely bound by their institutions and laws, but they give them life through their active engagement." An extended type of stakeholder theory is the Triple helix model, where governments, universities, and industry cooperate deliberately and with regulated forms as stakeholders for a desired development (Granquist and Nilsson 2016) with the community as the convenor (Nilsson 2007a).

\section{Blind Spot Theory}

Blind spot theory is based on the blind spot of the eye where the optic nerve enters the globe, which makes it impossible to see a whole panorama. Frequently, the viewer believes that she or he sees the whole view, especially if the surroundings are already well known and experienced. Cognitive physiologists have studied the understanding of some cognitive biases that affect decision making. These biased, or distorted reasoning, can have disastrous consequences. The bias blind spot described by cognitive psychologists is a tendency to recognize bias in others but not in oneself (Symborski et al. 2014). However, the blind spot 
theory that we describe, with regards to community development, is the failure to see multiple viewpoints. By missing such an impression, decision-makers sometimes fail to see hidden possibilities and angles representing alternative openings for development (Ricoeur 1981, Atkinson 1991). A variety of viewpoints helps developers and managers address possible flaws or take advantage of assets and link them to a larger development plan. However, to mitigate this blind spot in planning, a possible solution would be to engage in critical evaluation and selfawareness along with direct and equitable dialogues with multiple stakeholders. This sudden insight of missing such impressions may emerge as unintended drivers of development (Pronin et al. 2002, Cavanagh 2013, Nilsson 2017), opening for identifying developing processes. Such a shift of focus is often based on unintended, irreversible actions, connected to unpredictable causes (Nilsson 2007a, Schön 2010).

The blind spot theory can be used if there is readiness for decision-makers to back up group decisions. Alternatively, combined with disillusionment towards a change of the state, decision-makers can question firmly rooted and often imperturbable infrastructure, often consisting of networks and substantial investments (Abbasian 2016). An engagement in affectivity, cognition, and physical change can result in such a process (Geus et al. 2016, Olsen et al. 2016).

Chaos theory also forms the base for the blind spot theory, by its appearance of spontaneous and irreversible actions (Prigogine 1996, Kuhn 2012), and by its interest for centrifugal forces (Tol 2009). Chaos theory was discovered in the natural sciences in the field of nonlinear dynamics, while in the social sciences it is used in the understanding of the unpredictability, uncertainties, and nonlinearities of social systems behavior (Elliott and Kiel 1996). These forces may develop unintended directions resulting in change, often by a background of a mix of social and natural science within planning theory (Porter, 1990) linking clusters within different societal contexts (Baldacchino 2008, Rodger et al. 2009).

Perceptions of injustice, disorganization, and threats to quality of life caused by fast urbanization in the twentieth century pushed the evolution of planning while the academic field arrived only in the last quarter of the twentieth century (Healey 2001). Although centripetal forces left many rural peripheral areas at a disadvantage, however, a fast growing population in urban areas also led to complex social and governmental issues. Planning theory helped to provoke social and political movements in attempts to transform city governments to cope with systemic issues. In the early twentieth century, planning was generally understood as focused on how cities could and should be. However, by the end of the twentieth century an increasing awareness of new economic and social realities (Healey 2001), coupled with an interest in the quality of life and community development in both rural and urban regions, further developed the scope of planning theory. It is difficult to have one definition of planning theory. For example, Allmendinger (2017) described planning theory as 1) drawing from approaches in the natural and social sciences while acknowledging that one approach is not superior to the other; 2) there are multiple and competing views of planning; 3) and it recognizes the relationship between power and knowledge. 


\section{Methodology}

Our research investigates three cases over a longitudinal time frame over thirty years in a community context. The cases were selected based on first hand experiences within these particular communities and have been chosen as examples of the incremental development processes, especially the interplay between the two theories (stakeholder theory and blind spot theory) and the outcome of that interplay. Over time, through research and following up of each case, new evidence began to emerge. Multiple-case studies may have a distinct advantage and is described as being more robust (Herriott and Firestone 1983). Case study research is a research strategy focused on understanding the underlying forces involved (Eisenhardt 1989) in which the researcher explores a case or multiple cases over time and it can discuss explanatory, exploratory, and descriptive studies (Yin 2009). Approaches used for case study research can be qualitative, quantitative, or mixed methods and involves the processes of collecting detailed, in-depth data involving multiple sources of information (Creswell 2007).

The methods used for our longitudinal study involved a process of detailed, in-depth qualitative data collection and field observation within each village during the span of thirty years. Finally, a deeper analysis using qualitative interviews with villagers in each case was used to dive deeper into uncovering the final results of each community project following different outcomes of two theories-stakeholder theory and blind spot theory. Overall, the project is investigated by public documents, qualitative interviews, and newspaper articles. Each case was analyzed as a single case using both blind spot theory and stakeholder theory. Then a comparative method was used to see how these theories interacted with each other to facilitate coping strategies for some of the challenges that small rural villages face in sparsely populated regions.

In particular, for our empirical study, longitudinal analysis of specific events within the communities studied, significant findings began to emerge once the cases were analyzed together. It also describes how small organizations implemented rural tourism development projects while also describing the outcomes of each event as either a success or a lesson learned. Therefore, a multiple-case study approach was chosen because it was able to uncover a deeper understanding of the trends being investigated. In contrast, a single case study would not be able to uncover the patterns of the propositions fully. Our research emerged posteriori to help focus our work of the developing theories that were emerging. The case studies were chosen based on a Swedish peripheral geographical location, sparse and declining population, and the use of tourism as a community development or revitalization strategy.

The cases are reported separately in the results section in a chronological way allowing for the story of each case to be unfolded by the reader (Gustafsson 2017). In the discussion section, we will then make a comparison of each case tying together some evidence from published literature. Although there is limited literature on the concept of the blind spot theory; and our current longitudinal study may be one of the first to look at the interplay seen between stakeholder 
theory and blind spot theory. Nonetheless, in the conclusion section, we use the comparison of each case to help fully understand the overall findings.

\section{Results}

\section{Gillhov, Sweden}

This first case involves outcomes of launching a wolf symposium in Gillhov, a village with less than 50 inhabitants, located in the middle of Northern Sweden in the Berg Municipality with a population of 7,100 inhabitants (Statistics Sweden 2019). The community's primary industry is tourism, along with some woodbased manufacturing (Bergs kommun n.d.).

In the 1950s, a period of development optimism bloomed in Sweden, and the number of inhabitants in Gillhov rose to over 200, and the community decided to build a new spacious schoolhouse. With its substantial red brick walls and big rooms, the schoolhouse became a sign of modernity and the future. However, in the 1960s, the optimism faded away and inhabitants started to abandon Gillhov, similar to the rest of Northern Sweden. Over time, the last pupils disappeared and there was a discussion of whether to tear the schoolhouse down. Nevertheless, in 1991, the community decided to use it for national courses in nature studies, which became a successful activity during the 1990s (Sammanträdesprotokoll, Bergs kommun 1991).

A board was established at the school-house with ambitions to connect national nature field studies during summer and autumn (Sammanträdesprotokoll, Bergs kommun 1991). Students from elementary schools were invited, along with other people interested around Sweden to acquire more knowledge about nature. The nearby Mid Sweden University in Östersund was engaged and two researchers started to teach at the school in zoology and in tourism. A body of about ten researchers with experience from nature studies and political science was established (Vargsymposiet. Landsarkivet, Östersund n.d.). Besides the schoolhouse, there was a shop and a bus company.

One night in February 1994, four staff members gathered in the schoolhouse sauna. They were a zoologist, a tourism researcher, a manager of the field school, and a local wildlife tracker. The tracker reported that he had found wolf tracks just outside the village. From this information, the zoologist stated that Gillhov now had become the only place in Sweden where all four predators are found in the same area - bear, wolverine, lynx, and wolf. The tourism researcher saw the potential of establishing a wolf symposium in the schoolhouse. Having wolves around in the village was, however, not a popular idea among the villagers. Nonetheless, the zoologist contacted a world-renowned Canadian wolf researcher and invited him to coordinate the Wolf Symposium in Gillhov. After some time, the wolf researcher agreed and the National Nature Conservation Authority of Sweden supported the idea which bolstered the Wolf Symposium project.

The first wolf symposium was launched in March of 1994 with 78 visitors, including people from public boards in Sweden and Norway, representatives from 
different nature protection organizations, researchers from universities, and staff from the police authority (Vargsymposiet. Landsarkivet, Östersund n.d.). Local and national media covered the symposium, while the BBC covered it internationally. From the very start of the symposium it was open to everyone, even those who disliked the idea of wolves in the area, therefore the discussions could be rather fierce, and violence was not far away. Still, the broad-minded administration of the event made it easy for discussions and, luckily, no violence occurred. During evening dinners, people sat together at the same table regardless of their differences in views. In Gillhov, the community accepted the symposium despite the fear of wolves (Nilsson 1996). Many functions were carried out by local people including people from the municipal administration. For example, the bus driver received many tour orders, households in the villages had opportunities to host symposium visitors, and the village shop received a considerable increase in sales.

In 1998, the leader of the symposium moved away and a new leader was appointed. However, instead of connecting with the Wolf Symposium, he created a 'nature showroom' to give information for tourists and locals. The links to the community weakened and after a couple of years, he moved the nature showroom away from Gillhov. The move took the spirit away from the community as convenor of the symposium. In 2018, the symposium was closed, 14 years after the start (Östersunds-Posten 2018).

The question returned, "What to do with the schoolhouse?" In 2003, it was sold to a Dutch entrepreneur based in Holland (personal communication with Anders Englund, Department of Industry and Commerce, Berg, 3 April 2017). After that, there have been few activities in Gillhov. The owner aimed to offer conferences and rent out the schoolhouse to tourists and similar activities. However, by 2017, happenings were very scarce at the schoolhouse (personal communication with Eugène Jonai, Gillhov Education Center, 1 April 2017). The development of Gillhov has dwindled to a halt and the community administration staff does not recognize the word "wolf symposium" (personal communication with Anders Englund, Department of Industry and Commerce, Berg, 19 July 2017). The bus driver's son lives in the community but now works for a company for school bus driving (personal communication with resident in Gillhov, 17 April 2019). Of the 20 remaining houses in Gillhov, most are used as summer houses while the rest seem to be empty. The primary use of the schoolhouse occurs during the autumn when international berry pickers come to the village. The rest of the year, the owner is generally in Holland. The place seems to be doomed to a slow but irreversible extinction.

\section{Gimdalen, Sweden}

Our second case involves the outcome of launching a tourist establishment in Northern Sweden called the Country Club Gimdalen that was planned in the village of Gimdalen with a population of around 100 inhabitants (Statistics Sweden 2019). Gimdalen is located in Bräcke Municipality with a population of nearly 6,300 inhabitants (Statistics Sweden 2019). The primary industry in the 
municipality is tourism, along with some wood-based manufacturing. Gimdalen is a traditional settlement with forestry and small agriculture plots. A considerable attraction is a river with an abundance of fish, especially river trout and grayling. In 1968, the river became a national custody district for fishing, and in 1989 it joined the first district for catch and release angling in Sweden.

Bräcke Municipality administration is an active stakeholder in community development, including both politicians and staff members. Among local people in Gimdalen, there are individual stakeholders. For example, a famous photographer and a representative for fishing activities in the river Gimån with the assets of tarn fish. They have, together with many others, a vital readiness to do something for their village. An example of this was a plan for further development of Gimdalen, presented together with the community in 1995 (Projektidéplan över Gimdalsnäset 1995). The plan required an acquisition and exploitation of a piece of forest on an isthmus close to the river, just 100 to 200 meters to the village settlements. The fundamental idea was to develop resources based on what the river Gimån could offer and led by local landowners in Gimdalen. In 1995 with the help of a German entrepreneur, Erhard Zimmer, who was supported by a German travel organization, Der Part, and with local landowners' cooperation (Nilsson 2007b) they started a local tourism company called Gimdalen Upplevelser och Äventyr (Gimdalen Experiences and Adventure) to develop a holiday village idea called the Country Club Gimdalen (Projektidéplan över Gimdalsnäset 1995). The expected target groups were thought to be tourists from Scandinavian countries and Germany (Nilsson 2003).

After some years, a revised version of the plan was done and was presented to the villagers, supported by money from the Swedish governmental administration to cover any unfinanced costs. The overall plan was launched by villagers, with villagers and for villagers with financial support from Zimmer. Twelve landowners from Gimdalen were prepared to lease the area and, together with Zimmer, would have a majority of the stocks (Nilsson 2003). Since the Kälarne region (including the village of Gimdalen) was transferred from the municipality of Ragunda to the Bräcke municipality during the 1974 reform, politicians in Bräcke realized that they had to do something for the area to feel welcomed to the new reorganized municipality (Nilsson 2007b). Gimdalen was experiencing depopulation trends over time and wanted to develop tourism in the area as a form of revitalization efforts. However, because of the remoteness of the village it was difficult to market and find financing for the tourism project. Therefore, when a local from Gimdalen introduced Zimmer to the project as an entrepreneur with financial backing the local cooperative were pleased.

The Gimdalen Experiences and Adventure (GEA) project's plan for the holiday village included hotel service facilities - between 30-50 high quality cottages with occupancy of four to six people. Each cottage would represent different periods of Swedish history (Nilsson 2003) and would be managed by the local landowner (Nilsson 2007b). Information on local customs would be available in the cottages. The facilities would contain a restaurant, lounge, library and conference hall. Additionally, it would be run and operated by locals which were estimated at 20-30 people employing about $40 \%$ of the adult inhabitants (Nilsson 
2007b). The initiative was described by politicians and planners as a gift from heaven, especially since the financing was clear (Nilsson 2003).

After the GEA project plan was presented by the community at a meeting with the villagers, it was at first met with enthusiasm by most of the participants. Nevertheless, after a while, some villagers criticized the large scale of the project, insufficient anchoring among the villagers, and fear of German influence in the village. A campaign started in the local newspaper with criticism and xenophobic arguments, based on a fear of a German invasion - calling forth a picture of Germans as a people who caused problems wherever they go (Länstidningen 25 March 1995a, Länstidningen 27 March 1995, Länstidningen 15 May 1995). Interviews conducted in 1995 (Nilsson 2003) showed that there was both negative and positive support for the GEA project. Positive responses to the project were connected to feeling that the project had an almost unbelievable chance (Länstidningen 25 March 1995, Länstidningen 4 April 1995, Länstidningen 9 May 1995). However, the negative responses reflected xenophobic sentiments expressed in the local papers at the time.

Interviews conducted with villagers in 2017 showed that respondents felt that the criticism was found mostly among part-time residents with summer houses in the village, by those who worked outside the village, and by some young people (personal communication with residents, 24 May 2017). It was hard to know if the people who were negative towards the GEA project were in the majority. However, they dominated the press and the criticism was supported by a community official (Nilsson 2003). As a result of the negative opinion, however, Zimmer relinquished the idea. He described his decision in an interview in the local newspaper by saying that during the entire process, he met mostly positive reactions from politicians and residents, so he could not understand the criticism exposed in the newspapers and why it started (Länstidningen 27 September 1995). After the GEA project ceased, a period of inactivity started.

The focus of the original project was the Gimå River that is still running through the village. Soon, a villager and his wife revived possibilities to use the river as a draw for tourism to the area and leased a portion of the land near the river. The angling is still seen as an asset of the village but instead of a hotel to accommodate guests, they are now placed in huts or by local families (personal communication with residents, 24 May 2017). At the municipality office, the GEA is almost unknown today (personal communication with Liv Edström, Bräcke municipality 24 May 2017). The xenophobic expressions are found incomprehensible, and not one of the community staffers can believe that this had happened. Instead, they declare that Gimdalen, today, is a multicultural and prospering village (personal communication with community chairman Sven-Åke Draxten, 24 May 2017). The angling activities have attracted domestic and foreign in-movers. The population has increased, employment has developed, and there is only one empty house. Several of the stakeholders who initiated the GEA from the start are still living in the village; however, they are not active any longer with community development (personal communication with residents, 24 May 2017). 


\section{Bispgården, Sweden}

Our third and final case involves the outcome of launching the King Chulalongkorn memorial, also known as the Royal Thai Pavilion in northern Sweden, built in the 1990s in Utanede with a population of around 460 inhabitants (Statistics Sweden, 2020). Utanede is just outside Bispgården in the Ragunda Municipality (5,300 inh.) (Statistics Sweden 2019). The area is known for its beautiful nature, but also negatively impacted by socio economic problems, an aging population, and out-migration (Carlfjord, 2017). The main industry activity is the production of electric power generated from the river Indalsälven - one of the most exploited rivers in Sweden for hydroelectric power providing Stockholm with about half of the electric energy consumed. However, Ragunda municipality receives very little financial support from this industry which is considered creating national, but not local economic benefits. For example, all nine hydroelectric power plants are owned from outside of the community, employees are few and maintenance services are subcontracted from elsewhere (Carlfjord 2017). The primary economic industry of Ragunda is tourism with some wood-based manufacturing.

Dedicated stakeholders in Ragunda Municipality, besides the community board, are rare and are mostly active around tourism development. The community has today, besides the Royal Thai Pavilion, a dry waterfall due to a natural catastrophe called Döda fallet (the Dead Fall). The Royal Thai Pavilion is the only one of its kind outside of Thailand (Thailändska Paviljongen 2020). It is a very popular tourist attraction with a theater tribune that rotates around different scenes, used for performances during the summer season with famous national actors (Ragunda kommuns hemsida 2020). There is also a hydro-energy museum in Krångede, showing the development of the production of electricity over centuries (Ragunda kommuns hemsida 2020). These attractions require service from hotels, restaurants and private facilities. In Bispgården, there is a factory producing lifts for trucks, with a worldwide market that requires accommodations (personal communication with residents, 24 May 2017).

The background for this research is formulated form personal communication with residents on 24 May 2017. The story begins in 1897 by a visit of the Siamese King Chulalongkorn, who made a trip to the northern coastal part of Sweden. The Siamese king wanted to learn more about forestry since he had encouraged his people in Thailand to start a domestic forestry industry. His visit ended in Bispgården where he stayed over-night. By horse drawn wagon, he traveled the next day a couple of kilometers to Utanede where a riverboat was waiting for him to bring him to his trip's final destination in Sundsvall. The gravel road he traveled on was, in the 1940s, used for transport of timber to a hydroelectric power station at the river. Although the road had no official name it was called Chulalongkorn by locals and a road sign was put up with that name.

In 1992, some tourists from Thailand saw the sign and were told about the story of their king's visit. They became very excited and kissed the road and explained to a local politician in Ragunda that this road is holy for Thai people since King Chulalongkorn had used it. This politician saw possibilities to make the 
road a tourist attraction and decided, together with the local Thai people, to send an invitation to a Thai dancing group to Utanede. However, he forgot to authorize the invitation by the community board (personal communication with residents, 24 May 2017).

In Thailand, the invitation was erroneously seen as a royal invitation from Sweden, supported by the royal court and the king. A delegate of Thailand was sent to the municipality of Ragunda in 1993 with an offer to the Swedish king: a pavilion with a statue of King Chulalongkorn. It was impossible for the Swedish court to reject and King Karl Gustav had to accept it. Since the Swedish government did not wish to be involved, they delegated it to the royal representative in the region of Jämtland, who directly delegated it to the mayor of Ragunda. The mayor had, however, no funding possibilities from the Swedish government to receive such a gift (personal communication with residents, 24 May 2017).

As a result of the lack of coordination between both the Thai and Swedish governments, Sweden had to do something. It decided, together with the Thai government, in 1998 to establish a pavilion with the Thai king in Utanede, financed by the State of Thailand. Since then, it has been the responsibility of the municipality of Ragunda to care for the maintenance of the pavilion, even though the original decision had not been taken legally, stretching the already strained financial budget of an impoverished community (personal communication with residents, 24 May 2017).

After a fantastic start, the interest of the pavilion with the statue of Chulalongkorn faded away-since the novelty of the statue goes away once you have already seen it once. Visitation soon diminished. This was also due to restrictions from the Thai-Swedish organization that forbid all sorts of activities around the pavilion, which made the visit a bit boring. After a while, this has changed and there are activities around the pavilion but not enough to bear its costs, especially since the golden plates have to be cleaned, and the community has no money for the expense (personal communication with residents, 24 May 2017).

A meeting with local stakeholders took place in April 2019, and it was decided to revisit the Thai Embassy in Stockholm (Jämtlands Tidning 14 March 2019). A new meeting was held in May 2019 in Utanede with the Thai ambassador and the Ragunda chairman. This meeting resulted in the creation of a plan, financed by both the Thai and Swedish governments (Jämtlands Tidning 26 September 2019). In October 2019, a committee was established to finance and maintain the pavilion and in July 2020 during the $123^{\text {rd }}$ commemoration of King Chulalongkorn's visit to Ragunda discussions continued between Thailand and Ragunda municipality on ways to preserve the memorial in cooperation between governments, public, and private sectors in a sustainable way (Tingstam 2020). 


\section{Discussion}

\section{Theoretical Reflections}

Using a longitudinal case study analysis, this article tries to illuminate how the use of two theories - stakeholder theory and the blind spot theory — can establish development by an interplay between them. The blind spot theory is, however, not viable alone and the stakeholder theory can have a clear advantage by an interference between the two theories.

\section{Blind Spot Theory and Stakeholder Theory}

Blind spot theory is the idea that "the human mind has cognitive shortcomings... [therefore] ...not capable of finding the right development trend alone" and may lead to shortcomings because of the inability in seeing alternative solutions (Nilsson 2017, p. 153). However, it may also lead to positive outcomes if the community development project is also backed by the right stakeholders (Nilsson 2007a). Some rural areas had local forces that focused on an idea and hope for positive development that lead to 'planning with uncertainty' or collective planning based on 'liberty' to help find a rational way forward (Nilsson 2017). The communities highlighted from our case studies continue to face a negative economic trend, out-migration, and an aging population which created a need for advocates of positive community development (or community development for local good).

Prigogine (1996), speaking about chaos theory, states that we cannot avoid the feeling that we live in an age of transformation. Nevertheless, this transformation is sometimes unexpected with dramatic consequences, e.g., the standard example of a wing-beat of a butterfly in the Caribbean Sea creating a storm in Europe. We can also see these consequences on a much smaller scale if we are observant. The three examples in this article illuminate this. However, they also illuminate the apparent fact that positive change may not always appear - perhaps it very seldom does. The presented cases do not give a complete answer to the outcome of unintended effects of deliberate decisions and assumptions but they can give a hint of the unpredictable world we live in.

Community development based on blind spot theory seems to be successful at the start of the project's inception, but not decisively lasting over time. For example, the Wolf Symposium in Gillhov is a visible indicator of that. The start is totally according to Prigogine's (1979) observations of unintended development directions but the project itself did not last. The fundamental problem was a nonactive surrounding in the form of a lack of stakeholders. The entire project was dependent on one person and when this person disappeared, the symposium continued - it is true - but at another location and a different theme entirely. The devastating consequence resulted in a further spiral of decline for the village. The result showed that a blind spot theory is not enough to aid in success when dedicated stakeholders are absent.

When the cases are compared, the interactions between stakeholder theory and blind spot theory help us to draw important conclusions on the predictability 
of the success of community development initiatives. For example, each of our cases show that the original aim of each initiative was to create a sustainable positive development for their village. Unfortunately, the Wolf Symposium suffered internally from a lack of resiliency when the leader of the symposium moved away and the new leader changed the original concept from a wolf symposium to a nature showroom. The lack of active stakeholder to act as a convenor and stop the change of identity of the original project ultimately led to the project's termination.

When the case of Gimdalen is compared with Utanede we can see that the GEA project in Gimdalen was anchored in the village with multiple stakeholders and local support at the start. By that, it can be labeled as a typical stakeholder project. The only blind spot theory that interplayed with the project's outcomes was the coincidence that a German entrepreneur, Zimmer, wanted to finance the project. However, this ultimately led to xenophobic fears that created vociferous criticism which led to lack of support that finally terminated the project. In this case, stakeholders' conflicts with the project and lack of support by the local authorities led to the demise of the GEA. However, the outcome of the Royal Thai Pavilion started as a pure blind spot effect, but, like the GEA project, it was not supported by interested and active stakeholders at first, or rather the responsibility was delegated until responsibility came to a mutual accord years later. The Thai association had a decisive impact on the development but had no further ideas of how to make it sustainable at the start, until recently. The only active stakeholder at the start of the project was the community politicians, but they had no means as an active convenor to help towards financing. The outcome of the Royal Thai Pavilion shows how, at last, local interests saved the project with commercial influences, including the Thai government, the Swedish state, and the Thai Embassy in a collective decision to finance the project in the future. The project has become resilient.

\section{Conclusion}

The blind spot theory can form the background and becomes a key object for the study with the stakeholder theory as its litmus-paper of ability for success. The result shows that the blind spot theory can, by being subversive in a positive way, give overwhelming results. However, it can also be, in reality, a blind alley. In order to avoid this, the result shows that stakeholders are necessary, not just as starters, but also as supporters leading to resiliency of the overall project. Therefore, the key point is the blind spot theory and its relation to the stakeholder theory. For example, the Royal Thai Pavilion in Utanede, Sweden resulted in an unauthorized decision by a single person, followed by an invitation from royal officials from Thailand, which led to a misunderstanding between the two countries, resulting in an unwanted (and illegal) decision, which was later delegated to the Jämtland county governor, who then delegated it to the last link in the chain: the mayor of the municipality of Ragunda. However, nearly 30 years in 
the making, the Royal Thai Pavilion seems to be on the right path towards resiliency.

Results show that a convenor is necessary for long-term sustainability. Key stakeholders play a pivotal role in providing leadership and community development. Local authorities can help with governance and policies that can help with effective coordination of tourism development along with management of multi-stakeholder groups, financial and human resources, and community engagement (Salama 2018). As seen in our three case studies, a best practice approach for rural tourism development is to strive toward active engagement of the community as a convenor because grassroots leadership proves for a wide range of necessary development and promotion of tourism, as well as management of its potential impacts. Development based on a blind spot theory can be successful but obviously, it cannot depend on only one devoted person. It is necessary to have a group of devoted stakeholders, especially the community as a convenor must be involved. However, if a primary stakeholder disappears or changes the terms, someone else has to take the lead, to help maintain the integrity of the original concept. Since this did not happen in the case of the Wolf Symposium in Gillhov, Sweden the village is now almost depopulated.

For the case of the GEA project in Gimdalen, if the project had been supported by the municipality administration without faltering as a conscious convenor, the project may have proven to be successful. The new fishing project owners have anchored the development in the community center very well. The village is now recognized as a lucky example of a multicultural village with twelve different nationalities, partly due to in-movers with relatives both to the village and internationally (personal communication with Liv Edström, Bräcke municipality 24 May 2017). Although the positive outcomes of the Royal Thai Pavilion in Bispgården Municipality took the span of 30 years, the case study supports the fact that the blind spot theory has to be supported by interested and active stakeholders in order to be sustainable and, above all, be supported by a strong convenor.

\section{References}

Aarsæter N, Bærenholdt JO (2001) The reflexive North. Copenhagen: Nordic Council of Ministers.

Abbasian S (2016) Attitudes and factual considerations of regional actors towards experience industries and the tourism industry: a Swedish case study. Scandinavian Journal of Hospitality and Tourism 16(3): 225-242.

Adey P (2010) Mobility. London: Routledge.

Allmendinger P (2017) Planning theory. $3^{\text {rd }}$ Edition. Palgrave.

Ankre R, Nilsson PÅ (2016) Remote yet close: the question of accessibility in the Faroe Islands. In Archipelago Tourism: Policies and Practices, 137. Routledge.

Apostle R, Barrett G (1992) Emptying their nets, small capital and rural industrialization in the Nova Scotia fishing. University of Toronto Press.

Aquino JF, Kloes GMH (2020) Neolocalism, revitalization, and rural tourism development. In LJ Ingram, SL Slocum, CT Cavaliere (eds.), Neolocalism and Tourism: Understanding a Global Movement. Goodfellow Publishers. 
Aquino JF, Burns GL (2021) Creative Tourism: the path to a resilient rural Icelandic community. In K Scherf, G Edwards (eds.), Creative Tourism and Sustainable Development in Smaller Communities. Calgary: University of Calgary Press.

Armstrong H, Taylor J (1993) Regional economics and policy. New York: Harvester.

Atkinson A (1991) Principal of political ecology. London: Belhaven.

Backman F (2015) Making place for space: a history of Space Town Kiruna 1943-2000. Doctoral Dissertation. Umeå Universitet.

Baldacchino G (2008) Population dynamics from peripheral regions: a north Atlantic perspective. European Journal of Spatial Development 27: 1-19.

Baldacchino G, Milne D (2000) Lessons from the political economy of small islands. Charlottetown: University of Prince Edward Island.

Bauman Z (2017) Retrotopia. Cambridge: Polity.

Bergs kommun (n.d.) Tillväxtprogram 2040 (Growth Program 2040). Retrieved from: https://www.berg.se/foretagandeochutveckling/utvecklingochprojekt/tillvaxtprogram 2040.4.1c57773c166d61842912c195.html. [Accessed 21 July 2020]

Bondarenko VA, Israilova EA, Albekova SA, Albekova AA (2017) Difficulties and perspectives of incorporating Russian economy into the European economy and centripetal tendencies in the EU. European Research Studies Journal 20(1): 56-63.

Brooks T (2020) Saving multiculturalism with stakeholding: Hegel and the challenges of pluralism. SSRN Electronic Journal.

Brouder P (2013) Tourism development in peripheral areas: processes of local innovation and change in Northern Sweden, volume 26. Sundsvall: Mid Sweden University.

Cancino R (2014) Stakeholders in action. Aalborg University Press: Aalborg.

Carlfjord S (2017) Farewell welfare: local manifestations of the welfare society in two rural Swedish towns. Swedish University of Agricultural Sciences.

Cavanagh P (2013) The flash grab effect. Vision Research 91(Oct): 8-20.

Creswell JW (2007) Qualitative inquiry \& research design: choosing among five approaches. $2^{\text {nd }}$ Education. Thousand Oaks, CA: SAGE Publications, Inc.

Dahlström M, Aldea-Partanen A, Fellman K, Hedin S, Javakhisvili Larsen N (2006) Planning in the public domain: from knowledge to action. Princeton University Press.

Dluhosch B (2000) Industrial location and economic integration: centrifugal and centripetal forces in the New Europe. Cheltenham: Edward Elgar Publishing.

Eisenhardt KM (1989) Building theories from case study research. Academy of Management Review 14(4): 532-550.

Elliott E, Kiel LD (1996) Introduction. In LD Kiel, E Elliott (eds.), Chaos Theory in the Social Sciences: Foundations and Applications. Ann Arbor: University of Michigan Press.

Freeman E (2010) Stockholders and stakeholders: a new perspective on corporate governance. California Management Review 25(3): 88-106.

Freeman RE, Harrison JS, Wicks AC, Parmar BL, de Colle S (2010) Stakeholder theory: the state of the art. Cambridge: Cambridge University Press.

Getz D, Nilsson PÅ (2004) Responses of family businesses to extreme seasonality in demand: the case of Bornholm, Denmark. Tourism Management 25(1): 17-30.

Geus SD, Richards G, Toepoel V (2016) Conceptualisation and operationalisation of event and festival experiences: creation of an event experience scale. Scandinavian Journal of Hospitality and Tourism 16(3): 274-296.

Granquist SM, Nilsson P- $\AA$ (2016) Who's watching whom?-An interdisciplinary approach to the study of seal-watching tourism in Iceland. Journal of Cleaner Production 111(Nov): 471-478. 
Granquist S, Nilsson PÅ, Angerbjörn A (2019) From eco-tourism to ego-tourism: fluctuations in human view on nature over time. Athens Journal of Tourism 6(3): 195-210.

Gustafsson G (1991) Landscape, the individual and society - Change, meaning and goals. University of Karlstad.

Gustafsson J (2017) Single case studies vs. multiple case studies: a comparative study. Academy of Business, Engineering and Science Halmstad University, Sweden, 1-15.

Hall S, Gieben B (1992) Formations of modernity. Cambridge.

Healey P (2001) Planning theory: interaction with institutional contexts. In International Encyclopedia of the Social \& Behavioral Sciences, 11485-11491. Elsevier.

Herriott RE, Firestone WA (1983) Multisite qualitative policy research: optimizing description and generalizability. Educational Researcher 12(2): 14-19.

Jamal T, Getz D (1994) Collaboration theory and community tourism planning 22(1): 186-204.

Jämtlands Tidning (2019, March 14) Thailändska Paviljongen förfaller Kommunen har inga pengar underhailla (Thai pavilion is due the municipality has no money to maintain). Jämtlands Tidning.

Jämtlands Tidning (2019, September 26) Thaipaviljongen missade turistboomen (The Thai pavilion missed the tourist boom). Jämtlands Tidning.

Jana J, Marián H (2012) Creativity and rural tourism. Creative and Knowledge Society/ International Scientific Journal 2(2): 5-15.

Kuhn T (2012) The structure of scientific revolutions. Chicago: The University of Chicago Press.

Länstidningen, Östersund (1995a, March 25) Gimdalen klarar sig utan tyskar (Gimdalen manages without Germans). Letter to the editor. Länstidningen, Östersund.

Länstidningen, Östersund (1995b, March 25) Hotellprojektet på Näset gör Gimdalen till en framtidsby (The hotel project on Näset makes Gimdalen a future village). Letter to the editor. Länstidningen, Östersund.

Länstidningen, Östersund (1995, March 27) Tysk etablering $i$ Gimdalen skrämmer (German establishment in Gimdalen scares). Letter to the editor. Länstidningen, Östersund.

Länstidningen, Östersund (1995, April 4) Gimdalsprojektet en gudasänd gåva (The Gimdal project is a godsend gift). Letter to the editor. Länstidningen, Östersund.

Länstidningen, Östersund (1995, May 9) Sälj inte ut Gimdalsnäset (Do not sell Gimdalsnäset). Letter to the editor. Länstidningen, Östersund.

Länstidningen, Östersund (1995, May 15) Rädda Gimdalen (Save Gimdalen). Letter to the editor. Länstidningen, Östersund.

Länstidningen, Östersund (1995, September 27) Interview with E. Zimmer. Article by Ingvar Ericsson. Länstidningen, Östersund.

Martin T (2001) The reflexive community. The quest for autonomy as a coping strategy in an Inuit community. In N Aarsæter, JO Bærenholdt (eds.), The Reflexive North. Nord.

Nilsson PÅ (1996) Fyra essäer om Turismens historia $i$ Jämtland (Four essays on the history of tourism in Jämtland).

Nilsson PÅ (2003) Reflektioner om rekreativt kapital: Fallet Gimdalen (Reflections on recreational capital: the Gimdalen case). In M Larsson (ed.), Svensk turismforskning. Östersund: ETOUR.

Nilsson PÅ (2007a) Stakeholder theory. The need for a convenor. The case of Billund. Scandinavian Journal of Hospitality and Tourism Research 7(2): 171-184.

Nilsson PÅ (2007b) Recreation capital and accessibility to nature. Report for Center for Regional and Tourism Research. Nexø, Danmark. 
Nilsson PÅ (2013) Centripetal and centrifugal forces: a case study of regional push and pull factors for back-movers in Northern Iceland, the Faroe Islands and Northern Norway. Journal of Settlements and Spatial Planning 4(1): 87-94.

Nilsson PA (2017) The blind spot: how three cities in three different countries counteracted the crisis in the 1970s. Athens Journal of Architecture 3(2):151-176.

Nilsson PÅ, Arnason S, Helgadóttir G, Holm D (2011) Back movers and in movers: a study of back migration flows into small societies over time. Hammerdal.

Olsen K, Sverdrup T, Nesheim T, Kalleberg A (2016) Multiple foci of commitment in a professional service firm: balancing complex employment relations. Human Resource Management Journal 26(4): 390-407.

Östersunds-Posten (2018, February 6) För dålig uppslutning-vargsymposiet läggs ner efter årets upplaga (Too poor attendance - the wolf symposium is closed after this year's edition). Östersunds-Posten.

Porter M (1990) The competitive advantage of nations. MacMillan.

Prigogine I (1979) La nouvelle alliance: métamorphose de la science (The new alliance: metamorphoses of science). Paris: Editions Gallimard.

Prigogine I (1996) The laws of chaos. Review (Fernand Braudel Center) 19(1): 1-9.

Projektidéplan över Gimdalsnäset 1995 (Project concept plan for Gimdalsnäset 1995) Bräcke: Kommunkontoret.

Pronin E, Lin DY, Ross L (2002) The bias blind spot: perceptions of bias in self versus others. Personality and Social Psychology Bulletin 28(3): 369-381.

Ragunda kommuns hemsida (Ragunda Municipality webpage) (2020) Ragunda Kommuns Retrieved from: http://www.ragunda.se. [Accessed 25 November 2020]

Richardson KB (2015) Applied public relations. London: Routledge.

Ricoeur P (1981) Hermeneutics \& the human sciences. Cambridge University Press.

Rodger K, Moore SA, Newsome D (2009) Wildlife tourism, science and actor network theory. Annals of Tourism Research 36(4): 645-666.

Salama M (Ed.) (2018) Principles of sustainable project management. London: Goodfellow Publishers Ltd.

Salvatore R, Chiodo E, Fantini A (2018) Tourism transition in peripheral rural areas: theories, issues and strategies. Annals of Tourism Research 68(Nov): 41-51.

Sammanträdesprotokoll, Bergs kommun (Minutes from the municipality board) (1991) Dnr 1991.15, § 192.

Schön, L. (2010) Sweden's road to modernity. Stockholm: SNS.

Statistics Sweden (2019) The future population of Sweden 2020-2030: counties and classification of municipalities. Retrieved from: https://www.scb.se/contentassets/bcd a4f8050ab4bd496c7e12196bcb623/be0401_2020i30_sm_be18sm2002.pdf. [Accessed 25 November 2020]

Statistics Sweden (2020) Statistical database. Retrieved from: www.scb.se. [Accessed 25 November 2020]

Symborski C, Barton M, Quinn M, Kassam KS (2014) Missing: a serious game for the mitigation of cognitive biases. In Interservice/Industry Training, Simulation, and Education Conference (I/ITSEC) 2014 (pp. 1-13).

Terpstra P, Simonin B (1993) Strategic alliances in a triad. Journal of International Marketing 1(1): 4-25.

Thailändska Paviljongen, 2020. Thailändska Paviljongen (Thai Pavilion) Retrieved November 25, 2020, from www.thaipaviljongen.se

Thulemark M, Lundmark M, Heldt-Cassel S (2014) Tourism employment and creative inmigrants. Scandinavian Journal of Hospitality and Tourism 14(4): 403-421.

Timur S, Getz D (2002) Applying stakeholder theory to implementation of sustainable urban tourism. In K Wöbwer (ed.), City Tourism. Wien Springer. 
Tingstam T (2020) $123^{\text {rd }}$ Commemoration of King Chulalongkorn's Visit to Ragunda, Sweden. Retrieved from: http://thaiembassy.se/en/123rd-commemoration-of-kingchulalongkorns-visit-to-ragunda-sweden/. [Accessed 25 November 2020]

Tol RSJ (2009) Economic models for sustainable development. In V Bosetti, R Gerlagh, P Schleicher, Modelling Sustainable Development. Cheltenham: Elgar Publishing

Vargsymposiet. Landsarkivet, Östersund (The Wolf Symposium, Regional State Archive) (n.d.) Östersund.

Yin RK (2009) Case study research: design and methods. In L Bickman, DJ Rog (eds.), Essential Guide to Qualitative Methods in Organizational Research, volume 5. SAGE Publications. 